\title{
artículos
}

\section{Naked or nude?: Apuntes sobre publicidad y desnu- do en los anuncios de perfumes}

Noelia García Bandera

Investigadora vinculada a la UMA

PALABRAS CLAVE: Iconografía/ Publicidad

RESUMEN

La proliferación de imágenes publicitarias donde se muestra el cuerpo humano ha ido evolucionando y desposeyéndose de indumentaria hasta llegar al desnudo integral. Si bien, nuestra mirada está acostumbrada a ver la privacidad corpórea a través del arte y el cine, la publicidad sorprende por su puesta en escena.

ABSTRACT

The proliferation of advertising images in which we can see as the human body has developed and has relinquished its clothes until full-frontal nudity. Although we are used to seeing the corporeal privacy in Art and cinema, advertising surprises us due to the way they show it on stage.

Hablar del desnudo es hablar de la Historia del desnudo y fundamentalmente, es la figura femenina la que tanto en arte como en publicidad toma más protagonismo. Como diría Marie-Loup Sougez, "Desde que apareció la fotografía, la mujer fue su modelo privilegiado"1, aunque deberíamos especificar que su cuerpo es el que toma más importancia en la imagen fotográfica. No queremos hacer nuestra propia Historia, pues para leer sobre el tema hay obras, como la clásica de Kenneth Clark, El desnudo ${ }^{2}$, que introduce al lector en los más bellos y representativos desnudos del Arte. Interesa saber cómo la imagen de la mujer, desde la prehistoria, se representa desnuda, pero no será hasta la llegada de los griegos, sobre el siglo IV a. C., cuando Praxíteles realiza el "... primer canon femenino basado en la anatomía de la mujer." , por lo que no podemos considerar al desnudo como un tema artístico, sino como una forma artística inventada por los artistas griegos ${ }^{4}$. Con la llegada del

* GARCÍA BANDERA, Noelia: "Naked or Nude?: apuntes sobre publicidad y desnudo en los anuncios de perfumes", Boletín de Arte n²8, Departamento de Historia del Arte, Universidad de Málaga,2007, págs. 507522.

1 SOUGEZ, M.-L., "Sujeto y artífice, la mujer en la fotografía", en SOUGEZ, M.-L., y OLIVARES, R., Mujeres. 10 fotógrafas/50 retratos, Madrid, Estética y Pensamiento, 1994, pág. 9.

2 CLARK, K., El desnudo, Madrid, Alianza Forma, 1984, ( $2^{\mathrm{a}}$ ed.).

3 ROBERTSON, M.: cit. en SAURET, T., (coor.), Historia del arte y mujeres, Málaga, Universidad de Málaga, 


2: artículos Noelia García Bandera

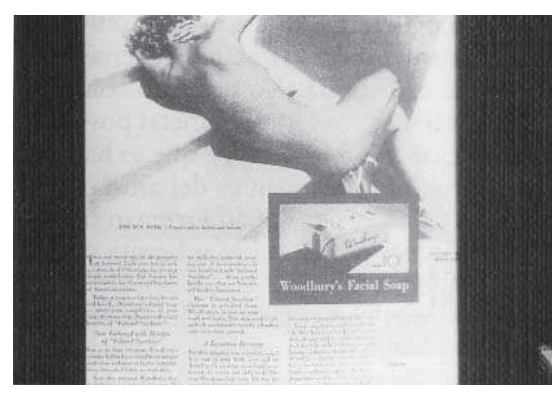

1. Jabón Woodbury (1936).

2. Venus con cuerno de Laussel (30.00025.000 a. C.).

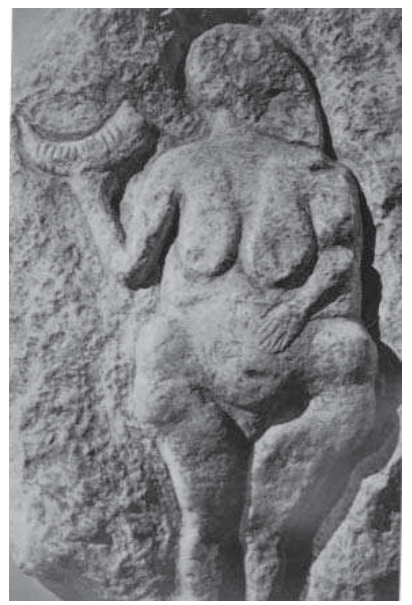

Renacimiento, el desnudo acapara gran parte de las obras artísticas. El siglo XIX hizo del cuerpo femenino un campo de hostilidades donde amor y odio se confundían. En general, el hombre blanco e instruido pensaba que sólo los salvajes y seres inferiores de otras razas podían vivir desnudos, pero si una persona era civilizada, ya fuera hombre o mujer, debía estar vestida ${ }^{5}$. Y si echamos un vistazo a las más representativas obras de desnudo de la historia del arte, nos damos cuenta que durante siglos, el cuerpo de la mujer ha servido para transmitir placer, mientras que el del hombre encarnaba escenas de tortura y muerte como batallas o martirios 6 ; de esta manera volvemos a encontrar la idea de mujer pasiva y hombre activo.

Pero si nos referimos a publicidad, el desnudo femenino aparece a finales del siglo XIX, principios del XX, donde las influencias románticas o simbolistas predominan 7 . Se podría considerar como el primer anuncio donde el sexo se introduce en la imagen de manera directa el del jabón Woodbury (1936) [1], donde el fotógrafo Edward Steichen (1879-1973) realizó un desnudo integral, con claros tintes pictorialistas, de una modelo de espaldas al espectador ${ }^{8}$.

1996., pág. 126 .

4 JULIUS, A., Transgresiones. El arte como provocación, Barcelona, Ediciones Destino, 2002, pág. 60.

5 LORENZO PEÑA, R. J., "Los comienzos de la fotografía y su visión del cuerpo humano" en BLANCO, C., MIÑAMBRES, A. y MIRANDA, T., (coor.), Pensando el cuerpo. Pensando desde un cuerpo, Albacete, Facultad de Humanidades de Albacete, Universidad de Castilla-La Mancha, 2002, pág. 220.

6 JULIUS, A., Op. Cit., pág. 60.

7 PÉREZ GAULI, J. C., El cuerpo en venta. Relación entre arte y publicidad, Madrid, Cátedra, 2000, pág. 44. 
2: artículos $\quad$ Naked o nude?: Apuntes sobre publicidad y desnudo...

Dando un salto en el tiempo, hoy en día los desnudos femeninos se acompañan de los masculinos, rompiendo de este modo trabas sociales y culturales que tanto han defendido la figura desnuda del hombre. Consecuencia de ello es que el hombre-objeto ha nacido, aunque la mujer-objeto cuenta con madurez absoluta, el hombre-objeto aún se encuentra en su niñez y mucho camino que andar.

Señalemos igualmente que mientras la publicidad está sujeta a todo tipo de censuras -según el país en el que se encuentre- en el arte, la representación del desnudo está socialmente aceptado 9 , por lo que hay mucha más libertad de expresión a la hora de pintar o esculpir que al fotografiar, ya que la imagen fotográfica es la más usada a la hora de realizar una campaña publicitaria ${ }^{10}$. Hemos comentado que desde los orígenes del arte, el desnudo siempre ha estado presente, sobre todo el femenino, pues tenemos el ejemplo del alto relieve de la Venus con cuerno de Laussel (30.000-25.000 a. C.) [2], pero en publicidad no será hasta finales de los ochenta, principio de los noventa, cuando se percaten de que el desnudo, o mejor dicho, la imagen erótica, usada inteligentemente, vende ${ }^{11}$.

Por lo tanto, el desnudo de un cuerpo, en nuestro caso el de la mujer, provoca, al menos, erotismo, y es un factor que no sólo llama la atención, sino que, como acabamos de decir, vende. No fue la fotografía quien descubrió el erotismo en el arte; ya la pintura del siglo XIX se hizo eco de la sexualidad femenina, aunque proporcionándole un toque perverso para que la atracción fuera mayor. Según Valeriano Bozal respecto a las obras de principios del siglo XX, "La imagen erótica repite los estereotipos y se mueve familiarmente en su seno, introduce algunos cambios para evitar la monotonía, pero siempre respeta un rasgo común: los modelos corporales establecidos"12. Estas claves se seguirán aplicando a lo largo de los años hasta llegar a nuestros días. De tal manera, el erotismo se ha convertido en uno de

8 Tristemente el autor del estudio no nos explica las consecuencias que generaron este bello desnudo fotográfico, pero seguramente, dio que hablar. EGUIZÁBAL, R., Fotografía publicitaria, Madrid, Cátedra, 2001, págs. 104 y 105

9 PÉREZ GAULí, J. C., Op. Cit., pág. 25.

10 No queremos ser tajantes en esta idea, pues sabemos muy bien los avatares que han tenido que pasar ciertas exposiciones $\mathrm{u}$ obras de arte antes de ser aceptadas. Pero queremos mirar cerca de nuestro presente $y$ citr en te y citar, en especial, la obra de un magnífico fotógrafo como era Robert Mapplethorpe. En 1990, Dennis Barrie, director del Instituto de Arte Contemporáneo de Cincinnati, fue denunciado, arrestado y acusado de inmoralidad a los tribunales a causa de una exposición de Mapplethorpe, la cual fue tachada como obscen por brindar sus fotografías que representaban desnudos masculinos y femeninos, bodegones florales y escenas sadomasoquistas. Desde un principio, se prohibió la entrada a menores de 18 años a la exposición y las imágenes más duras fueron expuestas en un lugar reservado. El juicio tomó gran importancia y protagonismo, donde numerosos expertos apoyaron la obra del difunto artista. Barrie fue absuelto, pues los cargos no pudieron ser sostenidos. Para más información, DANTO, A. C., Más allá de la caja de brillo. Las artes visuales desde la perspectiva posthistórica, Madrid, Akal, 2003, pág. 167 y ss.

11 PÉREZ GAULÍ, J. C., Op. Cit., págs. 245 y 246.

12 BOZAL, V., Los primeros diez años. 1900-1910, los orígenes del arte contemporáneo, Madrid, Visor, 1992, pág. 76. 
los recursos más usados en el lenguaje publicitario, pues la insinuación de un "final tórrido"13 se ha convertido en el arma eficaz de las grandes firmas de moda. Tal éxito se ha conseguido gracias a que el espectador ha tomado la postura de observador seducido, es decir voyeur ${ }^{14}$, y tanto un hombre como una mujer pueden tener la tentación de "mirar". En la década de 1850 se incrementó una nueva visión voyeurística gracias a la aparición del formato estereoscópico ${ }^{15}$, que consistía en un aparato binocular ideado en 1832 donde se podía visionar dos láminas repetidas con un ángulo de visión acorde con las distancia que separa los ojos ${ }^{16}$, por lo que se convertía en un artilugio perfecto e íntimo para mirar mujeres desnudas. Como dice Edward Lucie-Smith, "Cualquier representación erótica implica la presencia de un observador. Dado que el espectador es el observador, la conjunción de la imagen erótica y de la persona que la contempla supone ya un acto de voyeurismo"17.

En la historia del arte han existido grandes voyeurs como Ingres, Degas, Picasso, Duchamp o Helmut Newton que, inspirados en la representación del relato bíblico de Susana, han sabido jugar con el cuerpo de la mujer observada. Pero además, nos han convertido en auténticos "mirones" de los cuerpos desnudos, donde siempre existe una atracción y una curiosidad sexual de cualquier piel desprovista de vestimenta. Ese calificativo de "mirones" se debe enlazar con la idea de "mirar y no tocar". Un auténtico voyeur sólo observa, curiosea, mira. Marie-Laure Bernadac opina respecto al voyeur y la modelo que "Le femme reste inaccesible, destinée à être vue et non touchée"18, y realmente ahí se encuentra el juego erótico-visual.

La publicidad, aunque realmente es la sociedad, ha convertido el erotismo en pornografía; y ese cambio de término es el que molesta más a la mujer, pues de la artisticidad se cae en la vulgaridad. Incluso la prensa tiene apodo para este tipo de anuncios: "Porno 'chic""19, aunque bajo una idea discriminatoria contra la dignidad femenina. Según el periodista Roger Salas, "La publicidad de (...) perfumería, ha pasado vertiginosamente por un proceso calificable de loco destape en los últimos cinco años. Es lo que se lleva: explicitar más que insinuar, provocar por encima de sugerir.” 20 , y se pregunta, “¿Necesariamente, los anuncios de perfumes deben vender acoples sexuales?"21.

13 CUÉLLAR, M., y GALVín, V., "Sexo: todo vale", El País Semanal, 5 de agosto de 2001, pág. 29. 14 PÉREZ GAULI, J. C., Op. Cit., pág. 281.

15 EWING, W. A., El cuerpo. Fotografías de la configuración humana, Madrid, Siruela, 1996, pág. 208.

16 SOUGEZ, M.-L. y PÉREZ GALLARDO, H., Voz "Estereoscopia”, Diccionario de historia de la fotografía, Madrid, Cátedra, 2003, pág. 160.

17 LUCIE-SMITH, E., Ars erotica, Madrid, Libros y Libros, 1988, pág. 94.

18 BERNADAC, M.-L., "Histoires de l'oeil" en AA. VV., Féminimasculin. Le sexe de l'art, París, Gallimard, Electa, Centre Georges Pompidou, 1996, pág. 164. "La mujer permanece inaccesible, destinada a ser vista y no tocada".

19 PRIETO, J., "El porno 'chic' invade los anuncios”, El País, 29 de julio de 2001, pág. 12. 
2: artículos Naked o nude?: Apuntes sobre publicidad y desnudo...

La publicidad debe buscar imágenes impactantes, pues debemos tener en cuenta que la sociedad en la que vivimos, a raíz de todos los acontecimientos mundiales y su divulgación tanto en prensa escrita como en televisión, acepta la crudeza de lo ocurrido a nuestro alrededor, acostumbrándonos, cada vez más, a imágenes desconcertantes, ya sean por su contenido violento o sexual. De esta manera, Umberto Eco ya nos adelantaba ciertas tendencias al alegar, "La técnica publicitaria, (...), parece fundada en el presupuesto informativo de que un anuncio atrae más la atención cuanto más viola las normas comunicativas usuales (...)"22; por su parte y citando a Eco, el catedrático en Comunicación audiovisual y publicidad José Luis León afirma, "Las normas, los cánones, deben ser violados permanentemente, pues son predecibles, y la predecibilidad es enemiga de la atención y la seducción; de ello participan tanto el arte rupturista como la publicidad (...)"23.

Por lo tanto, ¿es malo transgredir las normas? Un interesante estudio realizado por Anthony Julius ${ }^{24}$ nos muestra el origen de la palabra "transgresión": ¿violar reglas? ¿Ir en contra de la ley? ¿Insultar? Todo ello puede ser recogido dentro de un contexto artístico e histórico, pero hoy día, tachar una obra como transgresora es todo un cumplido, ya que el artista ha sido capaz de ir más allá de las normas para conmocionar a un público expectante y necesitado de innovación.

Son dos versiones enfrentadas por la misma idea, la de R. Salas contra las de U. Eco, J. L. León y A. Julius. Reconozcamos que esta etapa histórica y social, ya la vivimos en las primeras décadas del siglo XX, cuando los artistas de vanguardia revolucionaron y provocaron el panorama artístico con movimientos como el fauvismo, el cubismo o el futurismo. Tales tendencias tuvieron que pasar la frontera de lo "políticamente correcto" para que sus nombres hayan quedado escritos en los libros de arte. $Y$ ahora le toca a la publicidad, que igualmente tendrá sus páginas reservadas en un futuro donde todos leeremos su historia y supervivencia hasta llegar a ser otro movimiento más.

Como acabamos de ver, y sin perder la idea del uso fotográfico, debemos señalar que en muchas ocasiones, la imagen fotográfica de un desnudo suscita más polémica que, por ejemplo, una pintura, llegando a enlazar el cuerpo desnudo fotografiado (de mujer) con una imagen pornográfica, pues "La desnudez es un estado del cuerpo que, (...), suele ser eventual y coyuntural"25, pues no solemos ir desnu-

20 SALAS, R., "El arte de la carne en los anuncios de moda", El País, 12 de mayo de 2002, pág. 8.

21 ídem.

22 ECO, U., La estructura ausente. Introducción a la semiótica, Barcelona, Editorial Lumen, 1994 (5a ed.), pág. 253.

23 LEÓN, J. L., Mitoanálisis de la publicidad, Barcelona, Ariel, 2001, pág. 31.

24 JULIUS, A.: Op. Cit., pág. 16 y ss.

25 ADSUARA, A., El cuerpo y la fotografía. Entre lo obsceno y lo artístico, Valencia, Midons, 1997, pág. 9. 


1: artículos Noelia García Bandera
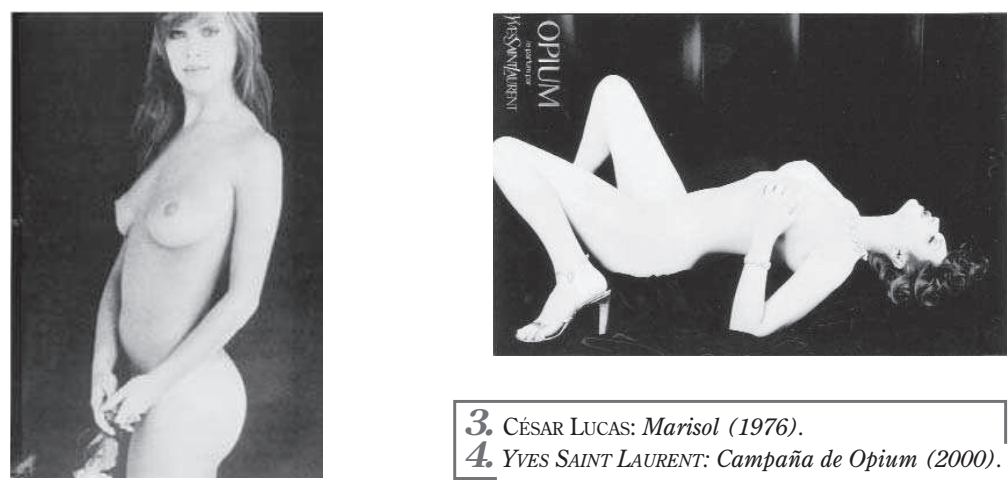

3. CÉSAR LUCAS: Marisol (1976)

4. YVES SAINT LAURENT: Campaña de Opium (2000).

dos a cualquier lugar. Ello se debe al realismo e inmediatez de tal medio, pues según Lynda Nead, "Si el objeto en cuestión es el cuerpo femenino, la fotografía puede verse como algo que permite el acceso directo del espectador al cuerpo, y la excitación sexual con un mínimo de interferencia por parte del propio medio"26. Por otro lado, el catedrático Juan Antonio Ramírez opina que "(...) un desnudo fotográfico contenía además el testimonio (la prueba) de que el fotógrafo había estado físicamente allí, delante del (o de la) modelo"27. Todo ello le da a la imagen desnuda captada por un objetivo fotográfico un aura erótico-morbosa que no deja que nos centremos en lo que nos quiere contar la fotografía. En primer lugar se piensa en ese realismo que la fotografía nos brinda, convirtiéndonos en auténticos voyeur, y en segundo lugar, el saber que entre el cuerpo desnudo y nosotros hay otra persona, que es el fotógrafo, que participó de su desnudez físicamente mucho antes que el espectador.

Por lo tanto, la fotografía no es libre a la hora de brindarnos un desnudo, sobre todo, si se trata de un desnudo femenino. Citemos un caso particular, donde una serie de elementos se unieron y crearon un sonoro escándalo. Tales elementos fueron: un fotógrafo, una modelo desnuda, una portada y los últimos flecos de una dictadura fascista. El fotógrafo era César Lucas (n. 1941); la modelo, Pepa Flores (n. 1948), popularmente conocida como Marisol; la portada, el primer desnudo de la revista Interviú; y la dictadura un régimen franquista que iba desapareciendo a favor de la Transición. Resulta que la "niña bonita" de tiempos del General Francisco Franco contrató a César Lucas para que le hiciera unas fotografías debido a su pro-

26 NEAD, L., El desnudo femenino. Arte, obscenidad y sexualidad, Madrid, Tecnos, 1998, pág. 156.

27 RAMíREZ, J. A., Corpus solus. Para un mapa del cuerpo en el arte contemporáneo, Madrid, Ediciones Siruela, 2003, pág. 34. 


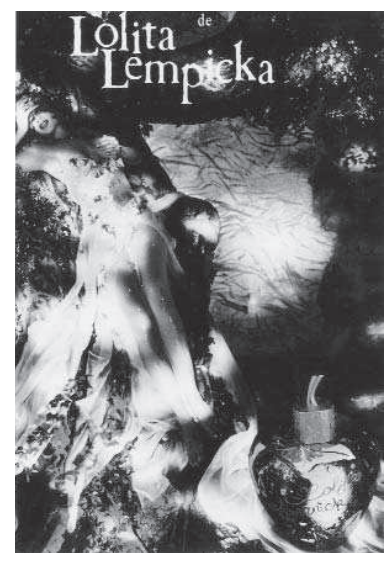

5. LOLITA LEMPICKA (1998).

moción personal. La popularidad de la actriz hizo que diversos medios periodísticos supieran de esas fotografías, por lo que se publicaron con un éxito enorme. El asombro llevó a la vergüenza, al ver a "La niña del cine español de la dictadura convertida en objeto de deseo adulto" 28 . Por lo tanto, el fotógrafo fue procesado por atentado a la moral y escándalo público, pero absuelto, poco después, "al no existir posturas procesales en dicha fotografía"29. La actriz mostró todo su apoyo a Lucas, y Marisol (1976) [3], sobrevivió a un atentado contra el arte, la mujer y el desnudo hasta llegar a nuestros días como símbolo de un triunfo de la libertad artística corporal y sensual.

Por desgracia, Marisol no cambió el mundo, y hay demasiados juicios morales que a comienzos del siglo XXI continúan causando polémica, aunque lo más curioso es el valor de causar tal polémica, tan cotizada en los mercados publicitarios.

Se ha puesto de moda hablar sobre una serie de anuncios que han revolucionado el mercado publicitario, quedándose en la mera imagen sin ir más allá de su posible significado. Por ello, debemos darle una oportunidad y brindarle un análisis que sobrepase la primera impresión.

Yves Saint Laurent, con una de las campañas de Opium (2000) [4], dejó a la mitad de la población sorprendida, y a la otra mitad molesta. Dirigida por Tom Ford y fotografiada por Steven Meisel, la imagen publicitaria muestra un desnudo integral de la polifacética modelo británica Sophie Dahl. La mujer se encuentra tendida, sobre una tela negra azulada, con las piernas abiertas, uno de sus senos al aire, mientras que el otro es acariciado por su mano. Su actitud implica provocación, osadía, descaro, pero en ningún momento se desprende vergüenza. Su piel es nacarada, como si de una muñeca de porcelana se tratase, su pelo rojo y arremolinado simula un "carácter demoniaco" 30 y travieso, su rostro, en pleno éxtasis, nos recuerda una imagen: la ninfa de la espalda quebrada ${ }^{31}$. Todas estas características se repetían en la imagen publicitaria de Lolita Lempicka (1998) [5], sólo que en esta

28 CONESA, C., “Objetivo: la mujer”, Descubrir el Arte, nº 40, (2002), pág. 37.

29 Idem.

30 CIRLOT, J. E., Voz "Cabellos", Diccionario de símbolos, Barcelona, Círculo de Lectores, 1998, pág. 118

31 Sería una ménade de la decadencia, resultado de las salvajes danzas que realizaba, para aliviar su his- 


Q artículos Noelia García Bandera

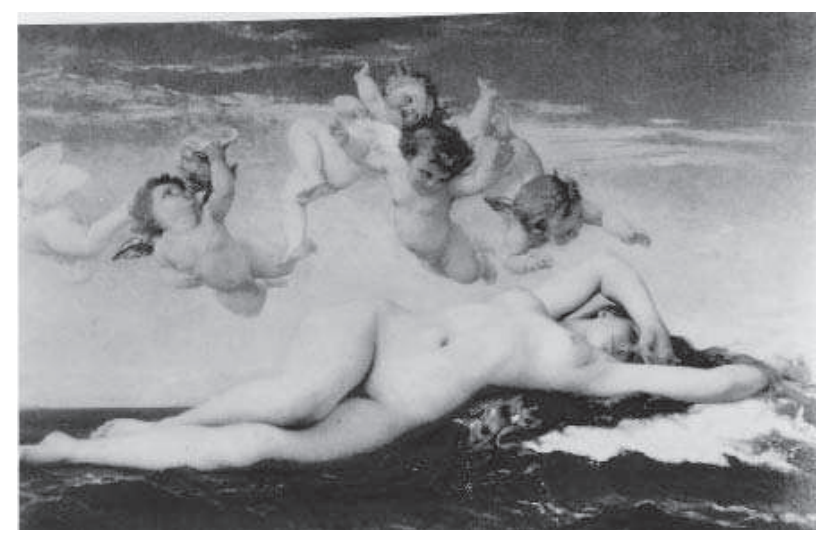

6. ALEXANDRE CABANET, El nacimiento de Venus (1863).

fotografía su cuerpo desnudo cobra todo el protagonismo, incluso recalcamos que uno de los detalles más provocadores es la exhibición y la falta de vello en el pubis ${ }^{32}$, detalle que escandalizó a la sociedad de 1800 cuando Francisco de Goya terminó La maja desnuda ${ }^{33}$. Ese triángulo formado tiene connotaciones divinas, pues el triángulo invertido puede representar, bajo una versión actual, a la diosa-madre ${ }^{34}$. $Y$ algo de divino, por cierto, tiene la modelo, ya que también nos podría recordar a un nacimiento, retomando de nuevo la idea de la propia Venus. Por ejemplo, se puede encontrar un parecido razonable con la premiada El nacimiento de Venus (1863) [6] de Alexandre Cabanel. Su sensual posición sobre las olas, su cabello libre, su desnudez, la Venus de Cabanel se llega a asemejar, aunque varios detalles nos llaman la atención en la imagen publicitaria que no aparecen en el cuadro, como las joyas y el

teria por su deseo hacia el hombre. De ahí vendría la palabra "ninfómana", que designa a una fémina con deseos sexuales incontrolables. Tras esta representación artística, los médicos descubririan que tal enfermedad existía, por lo que sería una buena excusa para explicar cualquier incés que la mujer uuia curmesexo. DIJKSTRA, B., Idolos de perversidad. La imagen de la mujer en la cultura de fin de siglo, Madrid, Editorial Debate, 1994, págs. 249-251.

32 En publicidad, la vagina es tema tabú. Cuando se muestra un desnudo femenino difícilmente se ve el sexo de la mujer, y cuando se enseña, suele estar sin vello. PÉREZ GAULI, J. C., op. cit., pág. 138.

33 Cierto es que la imagen de un pubis suscita polémica allá donde vaya, pero si repasamos los pubis en el arte, son más artísticos lo que carecen de vello, pues lo que poseen pelo púbico son impensables, tachados de obscenos e inmorales. Para más información, ADSUARA, A., Op. Cit., pág. 46.

34 REVILLA, F., Voz "Pubis", Diccionario de iconografía y simbología, Madrid, Cátedra, 1999, (3ª ed.), pág. 360 

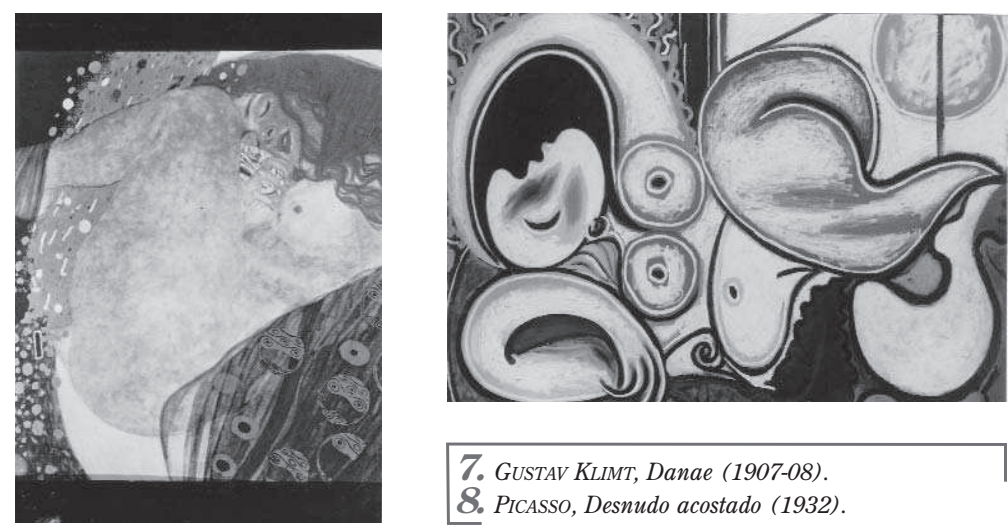

7. Gustav KLIMT, Danae (1907-08).

8. PICASSO, Desnudo acostado (1932).

calzado. Retomando la mentalidad decimonónica, para el hombre de esta época, el dinero era la raíz de todo mal, debido al deseo sexual de la mujer que se manifestaba a través de su vanidad y sus ansias de adornos, por lo tanto, el anhelo femenino del oro y del sexo era lo mismo ${ }^{35}$, incluso las joyas se asemejaban a "(...) una metáfora del sexo femenino, la ruina del hombre, un medio de seducción y una señal de esclavitud" 36 . El origen de esta cohibida idea nos llega de los primeros siglos del cristianismo, donde los Padres de la Iglesia condenaron con violencia el adorno femenino, ya que se asociaba a la desobediencia a Dios. Pensemos que la mujer no es nadie para retocar o mejorar la obra divina, la cual fue creada sin nada sobre su piel37. Ello llevaba a pensar que las mujeres se adornaban, no para gustarse a sí mismas, sino para deleitar y seducir a los hombres, por lo que se las tacha de figuras rebeldes y "desafiadoras de la obra divina"38.

De nuevo, cómo no, la eterna imagen de la femme fatal. Incluso su expresión orgásmica y su cabello rojo tiene otro referente tan sensual y carnal como la Danae (1907-08) [7] de Gustav Klimt, pues parece que está esperando ansiosamente a Zeus representado a través del semen dorado. Y cómo no, su posición recuerda a los innumerables desnudos que Picasso realizó en su etapa más sensual junto a Marie-Thérèse Walter, como Desnudo acostado (1932) [8], donde nos muestra un cuerpo femenino lleno de plasticidad, volumen y modelado, además de una piel

35 DIJKSTRA, B., Op. Cit., pág. 365 y 366.

36 Jules Bois cit. en DOTTIN-ORSINI, M., La mujer fatal (según ellos). Texto e imágenes de la misoginia fin de siglo, Buenos Aires, Ediciones de la Flor, 1996, pág. 84.

37 RIVERA GARRETAS, M.-M., El cuerpo indispensable. Significados del cuerpo de mujer, Madrid, Cuadernos Inacabados, horas y HORAS, 1996, págs. 63 y 64.

38 ídem. 
blanquecina y gesto de ardiente deseo.

Tanto ha trascendido esta campaña publicitaria que las autoridades británicas ordenaron en diciembre del 2000 la retirada de esta publicidad, alegando el director de control de publicidad Christopher Graham: "En tant qu'affiche, cette publicité a suscité clairement et largement une opposition"39. Desde que el cuerpo desnudo de Sophie Dahl se exponía en las calles británicas, un total de 730 quejas de todo el país llegó a manos de las autoridades, por lo tanto, decidieron que el motivo de esta imagen publicitaria contravenía el código de publicidad británica. Incluso se podría contemplar la imagen como un naked, en vez de como un nude 40 , es decir, y siguiendo a Kenneth Clark, "La lengua inglesa, (...), distingue entre el desnudo corporal (the naked) y el desnudo artístico (the nude)"41. Desnudo corporal viene a significar hallarnos sin ropa, pudiendo llevarnos a la vergüenza, mientras que el desnudo artístico, al ser una forma de arte, no llega a la inmoralidad extrema por no sentirnos incómodos al hacerlo, pues estaría dentro del disfraz de la propia piel y nunca se alcanza la desnudez ${ }^{42}$. Para nosotros, esta es la razón por la que "espantó" de esa manera a la sociedad británica, su desnudez, su gesto, su atracción, e incluso, su gran dimensión, pues tengamos en cuenta que normalmente los desnudos se ven en formato menor que el que puede abarcar una valla publicitaria. Contrarios a lo que opina Raúl Eguizábal43, consideramos que su piel, no por ser nacarada, fue censurada, sino por estar desnuda y gozar de un alto contenido sexual.

Pero también contó con aliados, como el continente australiano y su ASB (Advertising Standards Board), que consideraron que "the stylised and sensual presentation of a female did not demaen or objectify women" 44 . Y ahora pensemos, ¿es para tanto? Se ha llegado a vetar el desnudo integral de una mujer como si estuviéramos en pleno Concilio de Trento y su vertiente extrema del puritanismo anglosajón. La sufragista Mary Richardson encontró motivos suficientes para acuchillar La Venus del espejo de Velázquez en 1914, y la sociedad británica ha encontrado los suyos para retirar la campaña publicitaria de Opium de Yves Saint Laurent en el año

39 "Publicité élue de bleu" en www.bleu.org/opium.htm. "Como cartel, esta publicidad ha provocado una clara y amplia oposición".

40 "The last countryside for the Opium perfume of Yves the St. Lawrence puts in scene Sophie Dahl entirely naked" cit. www.perso.club-internet.fr/yangabin/.

41 CLARK, K., Op. Cit., pág. 17.

42 Cfr. BERGER, J., Modos de ver, Barcelona, Gustavo Gili, pág. 61 y 62.

43 Según Eguizábal, "En un reciente anuncio, al que ha rodeado un cierto escándalo en Inglaterra, donde ha sido prohibido, la modelo Sophie Dahl aparece desnuda con el aspecto de una muñeca de cera. Entendemos que no es el tratamiento sexual de la imagen lo que debe haber movido a los censores, sino el objetual: esa visión de una piel cerúlea, casi de porcelana, resulta demasiado fría para levantar alguna pasión", en EGUIZÁBAL, R., op. cit., pág. 199

44 "Where UK says no, this nation says yes please" En www.smh.com.aunews/0102/22/business/business/html, pág. 1. "... la presentación estilizada y sensual de una mujer ni la rebaja ni la convierte en objeto". 


\section{Q articulos Naked o nude?: Apuntes sobre publicidad y desnudo...}

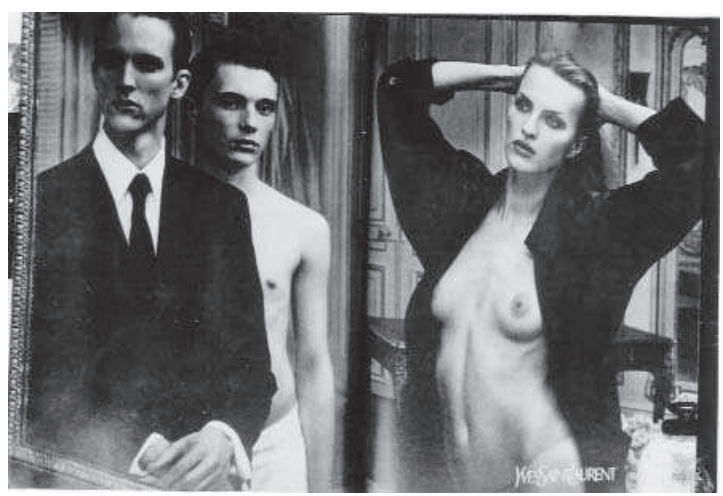

9. Yves SAINT LaURent, Campaña publicitaria "París", 2001.

200045 . Parece que en ciertos aspectos morales algunas sociedades no han cambiado a lo largo de los años. Habrá gustos de todo tipo, unos pensarán que es poco decoroso, otros sexual y otros, por qué no, una bella imagen, y cómo no, un desnudo artístico.

Yves Saint Laurent vuelve a sorprender con la nueva campaña publicitaria de Paris (2001) [9]. O deberíamos corregir y comenzar diciendo, "Tom Ford vuelve a sorprender con la nueva campaña...". Todo tiene su explicación. Tras el éxito/escándalo de Opium (2000) y su modelo Sophie Dahl, hay renovación de protagonista, fotógrafo y perfume. Ahora será la modelo rusa Anna Eirikh, el fotógrafo Mario Sorrenti y la fragancia Paris, quienes acaparen toda la atención. Pero Tom Ford continúa al frente de la dirección artística publicitaria, como lo hizo con la campaña anterior. La imagen es acusadamente narrativa, se transcribe como una especie de historia que nuestras mentes pueden forjar, ya que esta fotografía permite que la imaginación cree un principio y un final a la escena, revelando ciertos datos: una mujer y dos hombres. Algo más relata, por ejemplo, que se encuentran en una posible estancia parisiense, decimonónica, con aires burgueses. La imagen está encuadrada por un enorme marco que ofrece el reflejo de un espejo, pero sólo el reflejo, no a las personas. A la derecha, la joven mira su pecho desnudo, pues una especie de gabardina negra abierta es la única prenda que tapa su cuerpo, además de unas

45 Éste no ha sido el único anuncio que se ha tenido que retirar. Por ejemplo, Calvin Klein mostraba en las paredes de Time Square de Nueva York carteles donde se veían niños jugando en ropa interior sobre un sofá. La campaña tuvo que ser retirada. Para más información, EGUIZÁBAL, R., Op. Cit., pág. 38 y 39. 


Q: artículos Noelia García Bandera
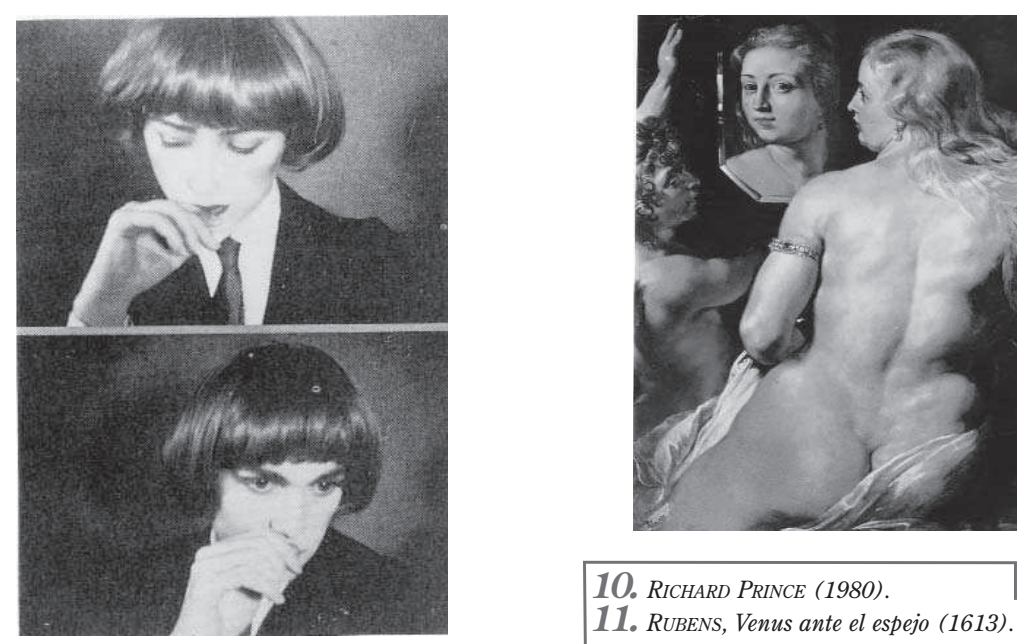

10. RICHARD PRINCE (1980).

11. RUBENS, Venus ante el espejo (1613).

diminutas bragas. Sus brazos se alzan y vuelve a tomar, como en otras campañas hemos visto, la pose tradicional de la Venus Anadiomene de Ingres. A la izquierda, dos hombres miran diferentes motivos. Por un lado, y en primer plano, un joven vestido con traje de chaqueta oscuro y corbata mira atentamente a la modelo, pero algo llama nuestra atención. Su rostro es andrógino, incluso imberbe, con facciones femeninas que simulan las de la joven, pero sus manos son masculinas y poderosas; su tamaño y su piel revelan su sexo. Por otro lado, justo detrás del joven, un adolescente también imberbe mira descaradamente al espectador, aunque con aires inocentes. Su pecho, aún sin formar se encuentra desnudo, y viste sólo unos pantalones blancos. Y así comienza la historia de esta especie de triángulo amoroso.

Podríamos pensar que la relación entre la modelo y el joven pudiera ser fraternal, por sus parecidos, pero el componente sexual invade la escena. $Y$ la presencia de ese adolescente perturba las simples apariencias. Algo parecido se contempla en la fotografía de Richard Prince (1980) [10], donde dos figuras no sólo en el aspecto, sino también en la gestualidad 46 , se confunden. Serían el propio artista y la polifacética Cindy Sherman quienes intercambian personalidades hasta acabar en un juego visual. A todo ello, y volviendo con el tema, hay que sumar la figura iconográfica del espejo. El espejo, sobre todo con respecto a la imagen de la mujer reflejada en él, es

46 DE DIEGO, E., El andrógino sexuado. Eternos ideales, nuevas estrategias de género, Madrid, Visor, 1992, pág. 178 . 


\section{Q artículos Naked o nude?: Apuntes sobre publicidad y desnudo...}

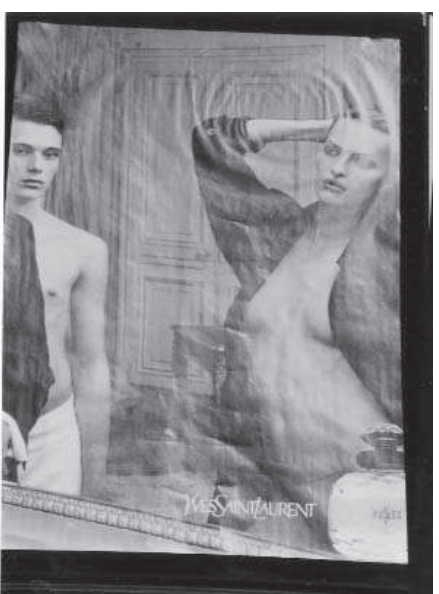

12. YVES SAINT LAURENT, "París" (vía pública).

atributo de la Vanidad. Una de las imágenes más comunes es la propia diosa de la Belleza y del Amor, Afrodita/Venus, reflejada, como pintara Pedro Pablo Rubens (1577-1640) en su obra Venus ante el espejo (1613) [11]. Pero la presencia masculina puede llevar a otra lectura, retomando las mentes masculinas del siglo XIX, y señalando que “... la mayoría de las pinturas populares de finales de siglo ofrecían admoniciones análogas a la mujer para que no mirase a hurtadillas en el espejo de la personalidad sin la supervisión mediadora de un hombre" 47 . Otra cuestión sería si una mujer de tales características necesita de la aprobación masculina, o tal vez, todo sea un juego, cómo no, erótico, pues el espejo representa una espontaneidad corporal que cualquier voyeur apreciaría48. Curiosamente, tras la joven en el ángulo inferior derecho, un ramo de rosas rosas da un toque de color a la escena. Es el símbolo que representa a esta fragancia. Pero la cuestión no acaba aquí, ya que la imagen ha ocasionado innumerables críticas, junto con la de Opium (2000). Yves Saint Laurent ha escrito una carta apuntando sus propias quejas, expresando que no desea tener control sobre las fragancias YSL, y ha encontrado los anuncios "vulgares" y en contra del espíritu de la compañía que él fundó 49 . El diseñador americano, creador de ambas campañas, se defiende, por un lado de Opium (2000) de la que dice que es "woman who has everything"50, y por otro de Paris (2001), “... Too bold?"51. Pues parece que sí, ha resultado tan atrevido que en la publicidad destinada a la vía pública, la gabardina ha aumentado su tamaño hasta tapar los pechos de la mujer [12], mientras que en la prensa escrita continúa enseñando su sensualidad 52 .

47 DIJKSTRA, B., Op. Cit., pág. 137.

48 RAmíreZ, J. A., Corpus solus... Op. Cit., pág. 46.

49 "Where UK say no, ... Op. Cit., pág. 1.

50 Ibídem., pág. 2. "... mujer que lo tiene todo".

51 "YSL plays the same old trick a more enchanting eye” en www.life.sohu.com/189, pág. 1. “¿Demasiado atrevido?".

52 Se han encontrado tres versiones sobre este anuncio: el anuncio completo con las tres figuras en horizontal; donde se ve a la joven, el chico imberbe y se presiente el joven en vertical; $y$ sólo la modelo sin compañía masculina en vertical. 


2: artículos Noelia García Bandera
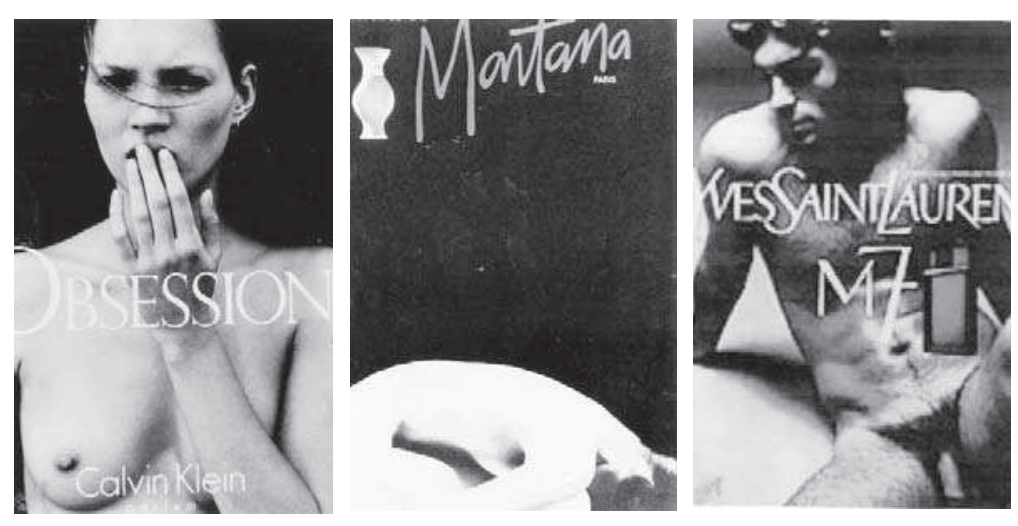

13. CALVIN KLEIN, Obsession (1995).

14. Montana (1992)

15. YVES SAINT LAURENT, perfume M7 (2002).

Realmente el debate debería centrarse en cuál de las dos imágenes atrae más, si un desnudo integral, o un semidesnudo, ya que cada fotografía tiene su encanto, y cada persona es libre de elegir.Aunque Yves Saint Laurent está revolucionando el mundo publicitario gracias a estos dos anuncios, no podemos olvidar otra mítica figura del escándalo como es Calvin Klein. Con su perfume Obsession (1995) [13] y su musa Kate Moss, brindó un desnudo de medio cuerpo, aunque no tan llamativo como los anteriores. La imagen de la joven se contempla natural, como si de un sueño acabara de despertar. Su mano se acerca a sus labios, como si estuviera bostezando, y sus ojos están medio cerrados. Uno de sus pechos queda totalmente al descubierto, mientras el otro es tapado por su brazo.

Señalamos el anuncio de Montana (1992) [14]. por una razón en particular. En mi artículo titulado "Iconografía femenina y publicidad de perfumes" (2000), señalo: "Un dato de interés sería, que por muy sexy o insinuante sea un anuncio, nunca aparece un desnudo integral, ya sea entre parejas o individualmente" 53 , afirmación que debo rectificar tras aparecer en el mercado, entre otros, el anuncio de Opium (2000) y brindarnos un desnudo donde el sexo de la mujer no se esconde, o más atrás en el tiempo, y revisando minuciosamente entre antiguas revistas, la imagen de Obsessión (1993) de Calvin Klein, donde la pareja comparte protagonismo. En cam-

53 GARCíA BANDERA, N., "Iconografía femenina y publicidad de perfumes", Boletín de Arte n²1, Málaga, Universidad de Málaga, 2000, pág. 378. 
2: artículos $\quad$ Naked o nude?: Apuntes sobre publicidad y desnudo...

bio, con Montana, aunque el desnudo sea completo, la identidad y el sexo explícito de la modelo se refugian a través de un fundido negro. Su cuerpo, con forma fetal, revela unas hermosas curvas gracias a la flexibilidad de la mujer. Un óvalo perfecto es diseñado por el cuerpo femenino.

Finalmente, tras un largo paseo entre las páginas de Internet, encontramos una imagen bastante sorprendente que creíamos una especie de "leyenda urbana". Yves Saint Laurent, con su perfume M7 (2002) [15], nos brinda un desnudo masculino del modelo francés Samuel de Cubre para la edición europea de Vogue, que no sólo han considerado los lectores americanos demasiado explícito, sino que también ha dejado estupefacto a los europeos. La imagen en blanco y negro muestra a un joven echado sobre el suelo con la mirada perdida y dubitativa. A través del juego de luces y sombras, se producen unos volúmenes y un cierto enigma alrededor de la identidad del hombre. Su torso es ocultado por el logotipo de la casa de modas y el frasco del perfume, mientras que su sexo se puede contemplar sin ningún problema en el margen inferior derecho. No estamos acostumbrados a esto. No es un desnudo como el de la última campaña de Lacoste, donde el modelo desprovisto de ropa alguna correteaba por una habitación y sólo su trasero era divisado. No. Ahora nos enfrentamos con lo que tanto hemos reclamado: la igualdad. Sophie Dahl nos mostró un sexo limpio, sin vello, muy artístico, dentro de un contexto erótico-sexual, y fue todo un escándalo en ciertos países.

Samuel de Cubre nos manifestó, sólo dos años después, un sexo varonil, poblado de vello y en calma, ¿y cuál es la reacción general? De ofensa. Por supuesto no todo el mundo está ofendido, pero al menos, sí sorprendido. ¿No es eso lo que busca la publicidad? Algunas mujeres francesas piensan que esta postura en "un homme, c'est laid"54. ¿Cómo? No lo llegamos a entender, ¿es que en una mujer está bonito? ¿Es que sólo puede ser sensual y erótica la imagen femenina? ¿Tan estereotipadas tenemos las mentes? ¿No son las mujeres más críticas incluso que los hombres? ¿O es que acaso esta imagen tiene un defecto? Pues sí, lo tiene bajo ciertas miradas. Su sexo en libertad no ha sido lo único que ha molestado al espectador. También ha molestado que el cuerpo del hombre esté cubierto de vello55. En pocos años, el ideal de belleza masculino se está imponiendo en el mundo occidental donde el modelo metrosexual es el que está, hoy por hoy, de moda. $Y$ por supuesto nos guiamos a través de las modas. Hace unos años, un hombre que tuviera vello en su cuerpo era lo más normal dentro de una estética masculina tradicional, sin tener que aludir al dicho popular que "el hombre, como el oso, contra más velludo, más hermoso". Pero hoy día, si nos damos un paseo por las playas o piscinas de nuestra ciu-

54 "Un homme un dans..." en www.romy.duhemverdiere.free.fr/carnet/2002/hommenu.html, "un hombre, está feo".

55 "Bear Essentials" en www.jcreport.com/archive/issue24/ 
dad, vemos jóvenes muchachos con perfectos y musculosos cuerpos depilados a los que no les importa sufrir por una buena causa: su belleza. Y todo ello ha llegado, no sólo porque la mujer ha comenzado a imponer sus gustos en la sociedad, sino también, porque ha empezado una especia de "guerra masculina de cuerpos bellos" donde los hombres compiten por ser los más guapos y los que tienen menos vellos en el cuerpo.

No queremos quitarle la parte de culpa a la publicidad, o mejor dicho, las grandes firmas de cosméticos y perfumes. Simplemente se quiere conseguir que los hombres sean tan consumistas como las mujeres cuando se trata de un sector nuevo en el ámbito varonil. Jean Paul Gaultier ha sido la primera factoría que ha lanzado al mercado una línea de maquillaje masculino y no dudamos que el resto de competidoras harán lo mismo pronto. Volvemos a la idea original: lo importante es vender, y si hay que convencer al hombre de que el maquillaje le va a ayudar a ser mejor y disfrutar más de la vida, pues se hace. Si no se tuvieron escrúpulos con la mujer y su cuerpo, tampoco lo tendrán con el hombre. Aunque con muchos años de diferencia, la "tiranía de la belleza" ya es unisex.

Volviendo a la campaña publicitaria, no nos ha asombrado que esta imagen causara polémica. Si Opium (2000) lo hizo, M7 (2002), no iba a ser menos. Es evidente que la sociedad aún no está acostumbrada a ver el sexo masculino sin tabúes, aunque estemos de acuerdo en este tipo de imágenes que para nada nos incomoda. Pero lo que más nos ha sorprendido es la llamada de atención sobre la estética masculina que ha suscitado. Cuando vemos una escultura griega de un kouros o el David de Miguel Ángel, por poner el ejemplo de escultura por similitud tridimensional con el ser humano, admiramos tanta belleza y esplendor en lo que en realidad son hombres desnudos. Pero cuando la fotografía nos describe el cuerpo de un hombre desnudo y lo exhibe ante una colectividad consumista, la sociedad piensa que aún no está preparada, pues el cuerpo de la mujer es más común en nuestras retinas.

No sabemos si esto es un "hombre objeto", sabemos que es un hombre desnudo. Y deberíamos ir acostumbrándonos a ello, pues si lo que la publicidad quiere es conmovernos, la imagen del hombre está aún "virgen" para tal fin. Las mujeres podemos ver esto como un paréntesis en el uso del cuerpo femenino, pero sólo eso, pues este tipo de imágenes de bellas modelos se seguirán consumiendo aunque el hombre y su sexo hagan aparición en escena. Lo único que debemos tener es la mente más abierta y enriquecernos con imágenes que no estamos acostumbrados a absorber visualmente, pues todo puede acrecentar una visión sobre nuestro mundo. 